NBER WORKING PAPER SERIES

\title{
MODEST, SECURE AND INFORMED: SUCCESSFUL DEVELOPMENT IN CONFLICT ZONES
}

\author{
Eli Berman \\ Joseph Felter \\ Jacob N. Shapiro \\ Erin Troland \\ Working Paper 18674 \\ http://www.nber.org/papers/w18674
NATIONAL BUREAU OF ECONOMIC RESEARCH
1050 Massachusetts Avenue
Cambridge, MA 02138
January 2013

We thank Morris Breitbart, Mathilde Emeriau and L. Choon Wang for outstanding research assistance and Aila Matanock for comments. Carrie Lee shared data on troop strength. We thank Michael Meese for discussion at the ASSA session "Economics of National Security." Seminar participants provided helpful comments at the University of Warwick, the Department for International Development (London), LUISS University, the Einaudi Institute, IFPRI (Addis Ababa), UNOUA(Addis Ababa), Tel Aviv University, the Hebrew University (Jerusalem), and the University of Haifa. This material is based upon research supported by the Air Force Office of Scientific Research (AFOSR) under Award No. FA9550-09-1-0314, and the Department of Homeland Security (DHS) under award 2010ST-061-RE0001 through the Center for Risk and Economic Analysis of Terrorism Events (CREATE) at the University of Southern California. Any opinions, findings, and conclusions or recommendations expressed in this publication are those of the authors and do not necessarily reflect those of any institution or of the National Bureau of Economic Research.

NBER working papers are circulated for discussion and comment purposes. They have not been peerreviewed or been subject to the review by the NBER Board of Directors that accompanies official NBER publications.

(C) 2013 by Eli Berman, Joseph Felter, Jacob N. Shapiro, and Erin Troland. All rights reserved. Short sections of text, not to exceed two paragraphs, may be quoted without explicit permission provided that full credit, including $\odot$ notice, is given to the source. 
Modest, Secure and Informed: Successful Development in Conflict Zones

Eli Berman, Joseph Felter, Jacob N. Shapiro, and Erin Troland

NBER Working Paper No. 18674

January 2013

JEL No. F52,F63,F68,H41,H56,K42,N45,O1,O17,Z1,Z12

\begin{abstract}
$\underline{\text { ABSTRACT }}$
Most interpretations of prevalent counterinsurgency theory imply that increasing government services will reduce rebel violence. Empirically, however, development programs and economic activity sometimes yield increased violence. Using new panel data on development spending in Iraq, we show that violence reducing effects of aid are greater when (a) projects are small, (b) troop strength is high, and (c) professional development expertise is available. These findings are consistent with a "hearts and minds" model, which predicts that violence reduction will result when projects are secure, valued by community members, and implementation is conditional on the behavior of non-combatants.
\end{abstract}

Eli Berman

Department of Economics, 508

University of California, San Diego 9500 Gilman Drive

La Jolla, CA 92093

and NBER

elib@ucsd.edu

Joseph Felter

CISAC and Hoover Institution

Stanford University

Encina Hall, C222

Stanford CA 94305-6165

felter@hoover.stanford.edu
Jacob N. Shapiro

Woodrow Wilson School of Public Policy and International Affairs

Princeton University

Robertson Hall

Princeton, NJ 08544-1013

jns@princeton.edu

Erin Troland

University of California

San Diego Department of Economics

9500 Gilman Drive \#0508

La Jolla, CA 92093-0508

etroland@ucsd.edu 
The economic analysis of civil wars and insurgencies has become a topic of growing interest in both the academic and policy communities (Blattman and Miguel 2010; World Development Report 2011). According to the 2011 World Development Report (WDR), a billion and a half people live in countries affected by fragility, conflict or violence, the last being a serious impediment to long-run economic development (WDR 2011). ${ }^{2}$ In those contexts, development programs are now often tasked not only with improving human welfare and enabling development, but also with helping local governments stabilize insecure environments (Berrebi and Olmstead 2011). ${ }^{3}$

Most interpretations of prevailing counterinsurgency theory imply that increasing the quantity or quality of government services will reduce violence (U.S. Army 2007). Yet the opposite effect is also plausible: increased economic activity in poorly controlled spaces might raise the returns to predatory violence, therefore motivating even more violence (Hirshleifer 1989; Collier 2000). Both anecdotal and empirical evidence are mixed. Sudden drops in aid flows correlate with increase violence across countries (Nielsen et. al. 2011) and certain kinds of aid appear to be violence reducing (Berman, Shapiro, and Felter 2011, hereafter BSF). Yet, exogenous increases in economic activity have also been shown to lead to increased violence against civilians (Vanden Eynde 2012, Berman et. al. 2012) and even development programs sometimes yield increased violence, either by creating rents to capture or by disturbing the distribution of power within communities (Crost, Felter, and Johnston 2012a). The literature has so far not explored the question of optimal development program design for violence-reduction. As stable governments

\footnotetext{
2 The link between property rights, security, and long-run growth in economics dates back to at least the pioneering work of Douglass North (1981). Svensson (1998), for example, extended North's work by modeling the effects of political instability on property rights and, in turn, on investment rates. Gradstein (2004) argues that the enforcement of property rights and economic growth are self-reinforcing. Guillaumont and Chauvet $(2003$ 7-10, 16) find that aid effectiveness declines with political instability. Building on this and related research, the WDR has emphasized the crucial role of improved governance in securing people and property if growth is to be achieved (WDR 2001,1).

3 For instance, USAID's top ten benefiting countries in 2012 (obligations) were Afghanistan (\$2.2B), Pakistan (0.9B), Jordan (0.5B), Ethiopia (0.4B), Haiti, Kenya and Iraq (0.3B each), DR Congo, Uganda and Tanzania (0.2B each) (USAID, 2013).
} 
graduate out of the class of countries requiring development assistance, an increasing share of aid will predictably be spent in fragile states, including conflict and post-conflict zones, so this gap in knowledge is deeply problematic.

In this paper we use detailed new data on development spending in Iraq to begin closing that gap. Using panel data on development assistance and violent incidents covering the first five years of the Iraq war, we compare the effects of U.S. government spending across several development programs, each with different characteristics. We are guided by the predictions of an information-centric, or "hearts and minds" theory of counterinsurgency in looking for characteristics of effective development program design. We estimate in first differences allowing for various controls to account for endogeneity and selection in the provision of development assistance (BSF, Flores and Nooruddin, 2009).

Consistent with the theory's predictions, we find that the violence reducing effects of aid are greater when (a) individual projects are small, (b) troop strength is high, and (c) professional development expertise is available. Controlling for the presence of combat troops and Provincial Reconstruction Teams (PRT), the small 915 person teams which provided development expertise to military units in Iraq, an additional $\$ 50$ per capita in spending on aid projects by military units through the Commander's Emergency Response Program (CERP) predicted about six less violent incident per 100,000 residents over the course of a half-year in the average district, which is equivalent to the sample mean, or approximately half the sample median in districts with ongoing fighting. ${ }^{4}$ For small CERP projects $(<\$ 50,000$ in project spending) that violence-reducing effect is six times stronger (i.e., \$8/capita to reduce violence by the sample mean). In contrast, most other development assistance programs, including those with large infrastructure projects, show no evidence of violence-reduction, with the exception of USAID's small-scale Community Stabilization Program (CSP).

As predicted by the theory, small scale spending and force levels complement each other; for every additional maneuver battalion (approx. 800 soldiers) present

4 These are observations (i.e., districts/half-years) with nonzero measured violence. 
in a district the violence-reducing effect of small CERP projects is roughly doubled. Development expertise also complements the violence-reducing effect of some development programs. The presence of a PRT amplifies violence reduction of CERP and CSP spending by between 50 and 200 percent, depending on the program.

Our findings should be useful in the design of development programs in conflict and post-conflict environments and may extend to fragile states in general, where assistance may be captured, extorted, or destroyed.

\section{Theory: Complementarity of Service Provision and Security in Counterinsurgency}

This section explores what an information-centric model of counterinsurgency implies about the complementarity between public service provision and security provision in generating stability. That complementarity is intuitive: government services should be of more value in a secure environment and security will be easier to provide if the local population gives information to security forces, which is more likely if the government provides basic services. To illustrate how the complementarity emerges we build on the three-sided game between government, rebels, and a community, presented in BSF. We first state the assumptions and equilibrium, referring to the original for motivation and proofs, and then develop the results on complementarity.

\section{A. Assumptions}

\section{Players and Actions}

The government, G, seeks to reduce violence through counterinsurgency effort and service provision. A rebel group, R, seeks to impose costs on government by attacking it. A utility maximizing community, C, can help deliver control of territory to government by anonymously sharing information about rebels.

\section{Sequence of Play}

Information sharing by the community requires no preparation so we assume that $\mathrm{C}$ moves last. Play proceeds in four stages. 
(1) Nature draws community norms favoring rebel control of their territory, $n$, from a uniform distribution $\mathrm{U}\left[n_{L}, n_{U}\right] ; n$ is private to $\mathrm{C}$.

(2) G chooses a level of public goods to provide, $g$, and a level of counterinsurgency effort, $m$. R simultaneously chooses a level of violence, $v$, to attempt against G. (Assume $n_{L}$ and $n_{U}$ span enough of the real line to allow $n_{L} \leq v+g \leq n_{U}$.)

(3) C decides how much information, $i$, to share with G, having observed the actions of $G$ and $R$.

(4) Uncertainty regarding control of territory, $a$, is resolved, and payoffs occur.

\section{Technology of control}

Control of territory is a binary state. The variable, $a$, is one if the government controls the territory, and zero if the territory is controlled by rebels. The probability of government control is

$$
\mathrm{P}(a=1)=\mathrm{h}(m) i,
$$

where $m$ is counterinsurgency effort by G, $(m \geq 0), \mathrm{h}(m): \mathrm{R}^{+} \rightarrow[0,1]$ is a

monotonically increasing, concave contest success function, with $h(0)=0$ and $h \rightarrow 1$ as $m \rightarrow \infty$. Here $i$ is the level of information that $C$ chooses to share with $G,(1 \geq i \geq 0)$. (All variables are real numbers unless otherwise specified.)

\section{Payoffs}

Community: Community utility is given by

$$
\mathrm{U}_{\mathrm{C}}(a, g, n, v)=\mathrm{u}(c+g-n) a+\mathrm{u}(c-v)(1-a) .
$$

If $a=1$ (government control) then the community consumes $c \geq 0$, and benefits from government services, $g \geq 0$, so it attains utility $\mathrm{U}_{\mathrm{C}}=\mathrm{u}(c+g-n)$, where $\mathrm{u}($.$) is$ continuously differentiable and monotonically increasing. Services are local public goods such as policing, dispute resolution, education, health clinics, utilities, and infrastructure. Community norms, $n$, generate disutility when government is in control. 
Alternatively, if $a=0$, rebels may successfully carry out violence, $v \geq 0$, against government targets. In that case community members will attain utility $\mathrm{U}_{\mathrm{C}}=\mathrm{u}(c-v)$. Rebel violence, $v$, is not directed against community members per se, but we assume that they suffer from it nonetheless, because they are accidentally affected by crossfire, empathize with government employees, or value government targets. In the case of rebel control the community does not benefit at all from government services, $g$, either because the government withdraws services when it cannot protect its employees and contractors, or because it conditions local public good provision on control, as collective punishment. Conditionality would be unusual for a social welfare maximizing government but is U.S. military policy in administering CERP (U.S. Army, 2006). Survey evidence reveals that a majority of CERP implementers in Afghanistan practice conditionality. ${ }^{5}$ This assumption is clearly extreme; it cannot fully apply to all types of services, such as roads which cannot be easily withdrawn. It could fully apply to services such as policing and justice, and might well partially apply to services such as health and education. We discuss the implications of relaxing conditionality below.

Incorporating the uncertainty that $\mathrm{C}$ faces about $a, \mathrm{C}$ 's expected payoff is

$$
\left.\mathrm{EU}_{\mathrm{C}}(g, v, n, p)\right|_{\mathrm{n}}=\mathrm{u}(c+g-n) \mathrm{h}(m) i+\mathrm{u}(c-v)(1-\mathrm{h}(m) i) .
$$

Rebels: Rebels use violence to impose costs on government, either in an attempt to extract concessions, or in an effort to overthrow the government altogether (Tilly, 1978). In the Iraqi context these attacks would be mostly improvised explosive device (IED) and direct fire attacks against Iraqi government or Coalition forces. Let G's cost of rebel violence be $\mathrm{A}(v)(1-a)$, which accounts for the damage caused by an attack. R's benefit from violence is then $\left.\mathrm{U}_{\mathrm{R}}=\mathrm{A}(v)\right)(1-a)$, where we assume that $\mathrm{A}(0)=0$ and that $\mathrm{A}$ is an increasing, concave function. Rebels' cost of violence is $\mathrm{B}(v)$, which is increasing and convex. (Henceforth, all functions are assumed to be twice continuously differentiable.) So R's expected payoff is

\footnotetext{
${ }^{5}$ See BSF for details.
} 


$$
\begin{aligned}
& \mathrm{EU}_{\mathrm{R}}(v, a)=\mathrm{E}[\mathrm{A}(v)(1-a)-\mathrm{B}(v)]=\mathrm{A}(v)(1-p)-\mathrm{B}(v), \\
& \text { where } p \equiv \mathrm{h}(m) \mathrm{E}(i) .
\end{aligned}
$$

Note that $p=\mathrm{P}(a=1)$ for rebels, for whom $i$ is a random variable.

Government: The government bears the costs of violence as well as the costs of violence mitigation (counterinsurgency), $m$, and of service provision, $g$, and gets expected utility

$$
\mathrm{EC}_{\mathrm{G}}(v, m, g, a)=\mathrm{E}[\mathrm{A}(v)(1-a)+\mathrm{D}(m)+\mathrm{H}(g)]=\mathrm{A}(v)(1-p)+\mathrm{D}(m)+\mathrm{H}(g) .
$$

We assume that $\mathrm{D}(0)=\mathrm{H}(0)=0$, that cost functions $\mathrm{D}($.) and $\mathrm{H}($.) are monotonically increasing, and that $\mathrm{A}\left(n_{U}\right)>\mathrm{D}^{\prime}(0)$, so that the fixed costs of $m$ are never so high that communities maximally predisposed to not share information are never cost effective for $\mathrm{G}$ to engage.

\section{B. Equilibrium}

We focus on subgame perfect Nash equilibrium in pure strategies, solving by backwards induction, starting with the community (step \#3).

Community: The community chooses $i$ on the closed interval $[0,1]$ to maximize,

$$
\left.\max _{0 \leq i \leq 1} \quad \mathrm{EU}_{\mathrm{C}}(i, g, n, v, m)\right|_{\mathrm{n}}=\mathrm{u}(c+g-n) p(m, i)+\mathrm{u}(c-v)(1-p(m, i)) .
$$

Anticipating results on complementarity, note that since the probability of control is proportional to information shared, public good provision and information are complements, as are counterinsurgency effort and information. Since $\mathrm{C}$ chooses $i$

$$
\begin{aligned}
\frac{\partial p}{\partial i}=\mathrm{h}(m), \text { so } \\
\quad 0 \geq \frac{\partial E U c}{\partial i}=\mathrm{u}(c+g-n) \mathrm{h}(m)-\mathrm{u}(c-v) \mathrm{h}(m),
\end{aligned}
$$

which implies that either $m=0$ or that the best response function of the community is

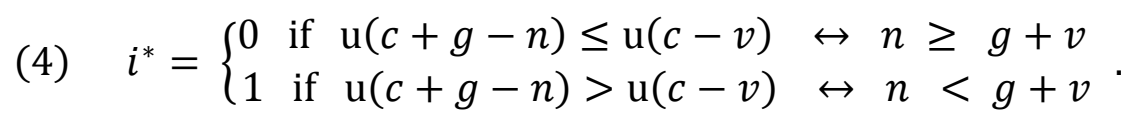

Consumption is neutral; it occurs whether information is shared or not. Norms favoring rebel control reduce incentives to provide $i$. 
Recalling our discussion of conditionality, we can now see why it matters. Higher $g$ induces $C$ to share information in (4). In the absence of conditionality $g$ would be enjoyed under both government and rebel control, and would provide no incentive for information sharing (i.e., $i^{*}=1 \leftrightarrow n<v$ ). So in the absence of conditionality, g will have no effect on information-sharing, and therefore no role in the model. In the context of the model's assumptions, then, any estimated effects we find of $g$ are evidence of conditionality.

Define $p^{*} \equiv p\left(i^{*}, m\right)$, the probability of government control anticipating optimal information sharing by the community. If $m>0$ then $\mathrm{E}\left(i^{*}\right)=\mathrm{P}\left(i^{*}=1\right)=\mathrm{P}(n<$ $g+v)=\mathrm{F}(g+v)=\left(g+v-n_{L}\right) f$, where $f=\frac{1}{n_{U}-n_{L}}$, the density of the uniform distribution, so that

$$
p^{*}=\left(g+v-n_{L}\right) f \mathrm{~h}(m) \text { if } m>0, p^{*}=0 \text { if } m=0
$$

Government: Continuing backwards through the sequence of play, the government anticipates (4) and solves

$$
\min _{g \geq 0, m \geq 0} \mathrm{E} \mathrm{C}_{\mathrm{G}}\left(v, m, g, p^{*}\right)=\mathrm{A}(v)\left[1-p^{*}\right]+\mathrm{D}(m)+\mathrm{H}(g) .
$$

G's first order condition for $m$ is $0 \leq \frac{\partial E C_{G}}{\partial m}=-\mathrm{A}(v)\left(g+v-n_{L}\right) f \mathrm{~h}^{\prime}(m)+\mathrm{D}^{\prime}(m)$. Under the mild assumption that $\mathrm{A}\left(n_{U}\right)>\mathrm{D}^{\prime}(0) \quad m=0$ cannot be a Nash equilibrium, which simplifies the analysis as it implies that $p^{*}>0$ in (5). See BSF for proof.

Turning to a solution for $m^{*}, \frac{\partial^{2} E C_{G}}{\partial m^{2}}=-\mathrm{A}(v)\left(g+v-h_{L}\right) f \mathrm{~h}^{\prime \prime}(m)+\mathrm{D} "(m)>0$, so $m$ has a unique interior solution for some $m^{*}>0$, given $v$ and $g$, defining a best response function $m^{*}(v, g)$.

The government also chooses a level of services, $g^{*}$, that solves the first order condition $0 \leq \frac{\partial E C_{G}}{\partial g}=-\mathrm{A}(v) f \mathrm{~h}(m)+\mathrm{H}^{\prime}(g) \cdot \frac{\partial^{2} E C_{G}}{\partial g^{2}}=\mathrm{H}^{\prime \prime}(g)>0$, which ensures a unique interior solution at some $g^{*}>0$, defining a best response function $g^{*}(v, m)$.

Solving cross partials and invoking the implicit function theorem BSF show that best response functions are upward sloping in violence: $\left.\frac{\partial g^{*}}{\partial v}\right|_{m}>0$, and $\left.\frac{\partial m^{*}}{\partial v}\right|_{g}>0$. 
Rebels: Rebels simultaneously choose a level of violence to maximize expected violence costs imposed on government, anticipating optimal behavior of $C$, as in (4).

$$
\max _{v \geq 0} \quad \mathrm{EU}_{\mathrm{R}}\left(v, g, m, p^{*}\right)=\mathrm{A}(v)\left[1-p^{*}\right]-\mathrm{B}(v) .
$$

Solving the first order condition for $v, 0 \geq \frac{\partial E U_{R}}{\partial v}=\mathrm{A}^{\prime}(v)\left[1-p^{*}\right]-\mathrm{A}(v) f \mathrm{~h}(m)-\mathrm{B}^{\prime}(v)$. The second order condition, $\frac{\partial^{2} E U_{R}}{\partial v^{2}}=\mathrm{A}^{\prime \prime}(v)\left[1-p^{*}\right]-2 \mathrm{~A}^{\prime}(v) f \mathrm{~h}(m)-\mathrm{B}^{\prime \prime}(v)<0$, so that $v^{*}$ is a unique maximum, given $g$ and $v$, thus the first order condition defines R's best response function $v^{*}(g, m)$.

R's choice of violence is decreasing in $g$. $\left(\left.\frac{\partial^{2} E U_{R}}{\partial v \partial g}\right|_{m}=-\mathrm{A}^{\prime}(v) f \mathrm{~h}(m)<0\right.$, which implies that $\left.\frac{\partial v^{*}}{\partial g}\right|_{m}<0$ by the implicit function theorem.) BSF confirm that partial equilibrium prediction empirically, a result that we will revisit below. R's choice of violence also decreases in $m$, (since $\left.\frac{\partial v^{*}}{\partial m}\right|_{g}<0$, since $\left.\frac{\partial^{2} E U_{R}}{\partial v \partial m}\right|_{g}=-\mathrm{A}^{\prime}(v)($ $\left.\left.g+v-n_{L}\right) f \mathrm{~h}^{\prime}(m)-\mathrm{A}(v) f \mathrm{~h}^{\prime}(m)<0\right)$.

Existence: Assembling results, we have a closed form solution for optimal information sharing by $\mathrm{C}$ in stage \#3, and three equations in three unknowns that determine best response functions $m^{*}(v, g)$ and $g^{*}(v, m)$ for $\mathrm{G}$, and $v^{*}(g, m)$ for $\mathrm{R}$ in stage \#2:

$$
\text { (4) } \begin{aligned}
i^{*}=\left\{\begin{array}{l}
0 \text { if } \mathrm{u}(c+g-n) \leq \mathrm{u}(c-v) \leftrightarrow n \geq g+v \\
1 \text { if } \mathrm{u}(c+g-n)>\mathrm{u}(c-v) \leftrightarrow n<g+v
\end{array} ;\right. \\
\text { (5) } \quad 0=\frac{\partial E C_{G}}{\partial m}=-\mathrm{A}(v)\left(g+v-n_{L}\right) f h^{\prime}(m)+\mathrm{D}^{\prime}\left(m^{*}\right) \\
0=\frac{\partial E C_{G}}{\partial g}=-\mathrm{A}(v) f+\mathrm{H}^{\prime}\left(g^{*}\right), \text { and } \\
0=\frac{\partial E U_{R}}{\partial v}=\mathrm{A}^{\prime}\left(v^{*}\right)\left[1-p^{*}\right]-\mathrm{A}\left(v^{*}\right) f \mathrm{~h}(m)-\mathrm{B}^{\prime}(v) .
\end{aligned}
$$

In the general case we cannot solve for closed form solutions for $m^{*}, g^{*}$ and $v^{*}$, but the concavity of $\mathrm{EU}_{\mathrm{R}}$ and the convexity of $\mathrm{EC}_{\mathrm{G}}$ ensure existence of a unique Nash equilibrium $(i, v, c, g) .^{6}$

\footnotetext{
${ }^{6}$ See Mas-Collel et al, proposition 8.D.3.
} 
[Figure 1 about here]

Figure 1 illustrates that equilibrium as point $A$ in violence - enforcement space, and in violence services space, as the intersection of downward sloping $v^{*}$ curves and an upward sloping $\mathrm{g}^{*}$ curve, (all conditional on the choice variable in the omitted dimension).

\section{Complementarity of service provision and enforcement}

How should government apply scarce resources to services and counterinsurgency

effort? The answer depends on the complementarity of those inputs, which requires a little explanation in a strategic context. Examining Figure 2a, we ask how the slope of the optimal response function $v^{*}$ will change when $g$ is increased, if it becomes steeper (i.e., more negative) then we will say that services complement counterinsurgency effort in inducing rebels to reduce violence.

Proposition 1: $d\left(\frac{\partial v^{*}}{\partial m} \mid g\right) / d g<0$.

Proof: See Appendix.

Note that this complementarity goes beyond a technological property such as the complementarity of inputs in a production function. It reflects instead the effect of $g$ in enhancing the violence reducing effect of $m$ on the optimal choice of violence by R. The intuition behind this complementarity is technological, though. It follows from the fact that $g$ complements $m$ in the probability of information sharing in (4). The proof shows that other countervailing forces are dominated by that technological complementarity.

The same intuition underlies the symmetric effect of $m$ on the violence reducing effects of $g$, as illustrated in Figure $2 \mathrm{~b}$, and stated in Proposition 2: $d\left(\left.\frac{\partial v^{*}}{\partial g}\right|_{m}\right) /_{d m}<0$.

Proof: See Appendix.

Note that the twin complementarity propositions describe partial equilibrium effects, which omit any additional shift in the $m^{*}$ curve, say, as a result of a change in $g$. This does not complicate the analysis since $m$ and $g$ are strategic 
complements (in the government's cost minimization). Thus, the general equilibrium effect of an exogenous increase in $g$ is a further reduction in violence, $v$, due to the induced increase in $m$, and the same is true of an exogenous increase in $m$.

Returning to the question of optimal allocation of resources for government, the problem is analogous to that of a production possibility curve, in which the violent strategic response of rebels is considered negative product. If we recast the government's problem as maximizing stability (negative violence) at minimal cost, Figure 3 reflects their optimum at point A. Complementarity implies that the production possibility curve is concave to the origin: neither enforcement nor service provision would ever optimally be provided alone, but always together. ${ }^{7}$

This result is quite general. A less restrictive social welfare function might include direct utility from service provision and utility (or disutility) from enforcement, which would generalize our linear indifference curve in Figure 3 by adding some curvature. Graphically, as long as that curve is not too concave to the origin (diminishing returns would imply convexity) the basic result holds: enforcement and service provision should always optimally appear in combination.

In section III below, we jointly test those two propositions using data on troop strength and development spending during the Iraq war.

\section{Data and Institutions}

Development assistance was provided by an unusually wide range of U.S. government actors in Iraq, most of whose activities are captured in our data. We measure aid spending using data from the U.S. Army Corps of Engineers Gulf Region Division's Iraq Reconstruction Management System (IRMS). These unclassified data include the start date, end date, project description, funding source, and amount spent for 62,966 aid projects projects awarded through December 2008. They include approximately $\$ 23$ billion in aid projects funded under a variety of

\footnotetext{
${ }^{7}$ Given the principle of complementarity, the optimal ratio of enforcement and service provision will reflect local conditions, varying across time and space.
} 
programs, including large-scale reconstruction spending through DOD administered programs such as the CERP, the Iraq Relief and Reconstruction Fund (IRRF), and various State Department programs including USAID activities funded through the Economic Support Fund (ESF). ${ }^{8}$

The U.S. military allocated roughly $\$ 3 \mathrm{~B}$ in aid through its CERP program. CERP funds were allocated in small amounts, mostly by units at the brigade level (approx. 3,000 soldiers) and below, without layers of subcontracting that made the relationship between dollars spent and work done tenuous for other reconstruction spending programs in Iraq. CERP spending was designed to work like $g$ in our model, by providing military commanders with resources to engage in small-scale projects to meet the needs of local communities, with the aim of garnering the population's support and cooperation. In practice, CERP funds were used to fund a broad range of projects, from salary payments to major infrastructure projects, though the majority went to small-scale local public goods. In contrast, non-CERP projects were often quite large, with a typical project being infrastructure for water and sanitation, or transportation. ${ }^{9}$

Besides DOD, the U.S. Agency for International Development (USAID) also provided small-scale aid funds in Iraq, through two main programs, the $\$ 560 \mathrm{M}$ Community Action Program (CAP) and the \$644M Community Stabilization Program (CSP). CAP ran from May 2003 through March 2010 and facilitated the creation and training of local community groups which then identified small infrastructure projects such as creating potable water storage tanks, wastewater and irrigation systems, and small construction projects, averaging approximately $\$ 101 \mathrm{k}$ in spending over 91 days. The theory behind the program was that communities with weak civic institutions were more vulnerable to insurgent influence and less able to demand the services they needed from the government. CSP ran from May 2006 through August 2009 and focused on funding job creation through training and small infrastructure projects in key cities, with the average project costing $\$ 77 \mathrm{k}$, and lasting 238 days. Importantly, CSP contractors tried to

8 See BSF for full details.

${ }^{9}$ For more information on data sources, see BSF. 
brand their projects as being conducted by the local government, not by USAID or the foreign NGO that implemented the program. While not explicitly tied to the military campaign, as was CERP, CAP and CSP represented the civilian-administered programs most like CERP in terms of project size and duration.

Our key dependent variable is the intensity of insurgent activity measured as the rate of attacks per capita against Coalition and Iraqi government forces. The attack data is based on 'significant activity' (SIGACT) reports by Coalition forces that capture a wide variety of information about “...executed enemy attacks targeted against coalition, Iraqi Security Forces (ISF), civilians, Iraqi infrastructure and government organizations." 10 These data provide the location and date of attack incidents between February 2004 and February 2009.

We have data on force levels from the Lee (2011) Order of Battle Dataset, which identifies the number of maneuver battalions (a.k.a. forces that are responsible for defined physical territory) present in a district for each month from February 2004 through December 2008. Lee's data were compiled using press reports and are described in detail in Lee (2012). Force allocation decisions in Iraq were driven by a combination of strategic imperatives and practical constraints. At the strategic level commanders moved battalions for a number of reasons, including removing them from areas deemed to be pacified. For instance, after the large $3^{\text {rd }}$ Armored Cavalry Regiment (approx. 4,700 soldiers) reduced the violence in Tal Afar from spring-2005 through spring-2006 it was replaced by a cavalry squadron (approx. 800 soldiers). Alternatively, battalions were moved to areas deemed to be more strategically vital, as when the additional forces sent to Iraq as part of the 2007 Surge were deployed in Baghdad and neighboring districts. To understand the possible endogeneity of force levels in a particular district $x$ half year, it's important to note organizational constraints. While there was surely an intention to allocate battalions dynamically to the area of greatest need, the combination of troop rotation schedules, and an organizational interest in maintaining unit cohesion and

10 GAO (2007), DOD (2008). The information provided in the Unclassified SIGACT data are limited to the fact of and type of terrorist/ insurgent attacks (including IED's) and the estimated date and location they occurred. See BSF for full details. 
developing local knowledge among deployed battalions would tightly constrain a commanders' ability to reallocate troops in groups of less than about 800 . Thus, in the context of our model the marginal cost of additional $m$ to a district was quite high.

Provincial Reconstruction Team locations are coded using information gathered from a set of maps provided by the State Department PRT office. US PRTs were first established in late 2005, and that number rose to twenty by the second half of 2008, each in a separate district. We do not count PRTs of other Coalition forces, assuming that they would be less relevant for US development program spending.

Appendix Table 1 provides descriptive statistics.

\section{Results}

Our empirical strategy is a straightforward first-differences design in which we regress changes on conflict on changes in various kinds of aid spending, controlling for lagged changes in violence and changes in Coalition force levels.

Our basic estimating equation is:

$v_{i, t}-v_{i, t-1}=\beta_{1}\left(g_{i, t}-g_{i, t-1}\right)+\beta_{2}\left(m_{i, t}-m_{i, t-1}\right)+\beta_{3}\left(v_{i, t-1}-v_{i, t-2}\right)+\delta_{t}+\varepsilon_{i, t}$, where $v_{i, t}$ is the number of insurgent attacks (incidents) in district $i$ in period $t, g_{i, t}$ is the amount of development spending of a given type, $\delta_{t}$ is a year fixed effect to account for the broad secular trends in the war, and $m_{i, t}$ captures the number of maneuver battalions in district $i$ in period $t$. The lagged change in violence, $v_{i, t}$, is included to account for short term, district-specific trends. Since broad trends in violence differed for Sunni areas, we also include a separate year fixed effect interacted with the proportion of Sunni voters. ${ }^{11}$

Our empirical strategy will identify the causal impact of changes in aid spending if either the omitted variables linking aid spending to insurgent violence are entirely a function of unit-specific trends or if their influence on aid spending is accounted for by past changes in violence and changes in troop levels. The major

${ }^{11}$ See BSF (2011) for a more detailed discussion. 
challenge is the possibility of a positive endogeneity bias if, conditional on trends and other controls, increases in residual violence are anticipated and responded to by application of more $g$ or $m$, in a half-year interval. That would cause our estimates to understate the violence-reducing effects of both $g$ and $m$. The logistic constraints and lags built into the allocation and implementation of both development spending and effective patrols to a district make that type of rapid response (within a half-year) difficult but not impossible. For that reason we tried specifications with various controls to investigate robustness.

Table 1 describes our first set of results, showing that small scale reconstruction spending is violence reducing on average $\left(\beta_{1}<0\right)$ but other types of reconstruction spending are often not. Column (1) replicates the main empirical result of BSF, that CERP is violence-reducing. Column (2) demonstrates that the CERP coefficient is robust to including troop strength $(\mathrm{m})$ on the right hand side, which BSF did not, indicating that violence-reduction is not due to CERP spending acting as a proxy for the presence of coercive force, $m$. Note that the coefficient on troop strength does not indicate violence reduction -if anything the positive coefficient on contemporaneous troop strength indicates that troops increase violence, which is inconsistent with the predictions of our theory. We don't think that this finding overturns the validity of the theory for two reasons: First, the incident data are reported by the troops themselves, so that there is a built in upward bias in locations which have troops present. Second, there appears to be a short term increase in violence on arrival which fades after about half a year, which we suspect is due to a short term learning process in which new troops are initially challenged by insurgents, who then withdraw as the troops develop situational awareness in their area of operations. The sum of the coefficient on contemporaneous troop strength and that on the lag is almost always statistically zero, and will be negative in some of the specifications reported below. Thus, once the upward reporting bias is accounted for, and allowing for a positive endogeneity bias -as described above, the cumulative effect of troop strength appears to be violence reduction (by an unknown amount) after about six months. (Including a 
third -one year-lag of troop strength does not substantively alter any of those conclusions.)

Returning to our discussion of development spending, columns (3) and (4) replicate another main result of BSF, that small CERP is six times as violencereducing per dollar spent than is large CERP, and demonstrate that those results are also robust to the inclusion of troop strength. The remaining columns report the effect of other programs, showing that only one of them, the Community Stabilization Program (CSP), shows evidence of being violence-reducing. Neither changes in large non-CERP reconstruction project, changes in small non-CERP reconstruction projects, changes in USAID spending through the CAP program, nor changes in overall USAID spending are significantly correlated with changes in insurgent attacks. While none of those programs (non-CERP large or small, CAP or USAID spending in general) show effects that are statistically different from zero, with the exception of CSP, they are all statistically less violence-reducing than is small CERP (at $\alpha=.05$ ), including large-CERP (as reported in the final row of Table 1).

Why are CERP and CSP violence-reducing while other programs are not, and why is small CERP especially so? Firstly, it's worth noting that this contrast reflects the larger literature, in which economic activity, and even aid programs, are sometimes associated with increased violence (i.e., predation, as Berman et al 2012 find in the Philippines, for example) and sometimes with decreased violence, as the theory in section II predicts. Recalling the driving forces of that theory: programs must be conducted in territory secure enough to be implementable, their design must be sufficiently informed about local preferences to benefit the local community; and they must be conditional on cooperation (i.e., information sharing). Those criteria are consistent with the pattern of results in Table 1. CERP programs are unusual in that they are secure by design, as they are administered by military units operating in the area. Smaller programs such as CSP, CAP and CERP tend to be better informed, because they are more likely designed in consultation with the local community. And smaller programs are more easily conditioned on the cooperation of communities, in contrast to large infrastructure projects (such as 
building a water or sewerage system) which cannot easily be revoked. Moreover, survey evidence from Afghanistan reveals that CERP was generally implemented conditionally (see BSF, footnote 11), in contrast to how a development agency such as USAID would typically implement programs, in accordance with a development objective rather than a security objective.

Having discussed how those criteria can rationalize the results in Table 1, we turn now to testing the implications of that theory. We examine whether security and development expertise complement programs for which we have evidence of effectiveness from Table 1, namely CERP and CSP.

Table 2 tests the hypothesis that security and development are complements, at the district level. Recall that these are actually two conceptually distinct hypotheses (Propositions 1 and 2), since in the context of model complementarity need not be symmetric. Notwithstanding that subtlety, we can test these hypotheses only jointly, by estimating the coefficient $\gamma$ on the interaction of $m$ and $g$ in the following estimating equation.

$$
\begin{aligned}
v_{i, t}-v_{i, t-1}= & \beta_{1}\left(g_{i, t}-g_{i, t-1}\right)+\beta_{2}\left(m_{i, t}-m_{i, t-1}\right)+\beta_{3}\left(v_{i, t-1}-v_{i, t-2}\right) \\
& \gamma_{1}\left(g_{i, t}-g_{i, t-1}\right)\left(m_{i, t}-m_{i, t-1}\right)+\delta_{t}+\varepsilon_{i, t} .
\end{aligned}
$$

Should both propositions hold then $\gamma_{1}$ will be negative.

Before turning to results, an issue of measurement requires attention. The model provides no guidance as to how $m$ should be measured (and doctrine is also unclear). What we seek is the capacity of the government to apply coercive force in order to suppress rebel activity. Until now we've measured troop strength in battalions per district, which would be an adequate approximation if troops per physical area were appropriate, following the logic of the response time to a tip or incident being critical. Alternatively, troops per capita would be a good approximation of the ability of the government to police and protect individuals. In Table 2 we report results using both approaches. ${ }^{12}$

\footnotetext{
12 The results in Tables 1 and 3 are qualitatively robust to replacing battalions per district with battalions per capita, as reported in Appendix Tables 2 and 3.
} 
The left panel of Table 2 reports both main and interaction effects of spending on small CERP, large CERP and CSP (columns (1), (2) and (3)). As predicted by the complementarity propositions, the estimated interaction term is negative in each case. All three coefficients are precisely enough estimated to reject the hypothesis of a zero coefficient in favor of the alternative of complementarity. The right panel checks robustness to measuring troop strength in battalions per capita (as opposed to per district), again for each of the three programs. The evidence for complementarity in this case is weaker, but consistent with the previous results: two of the three coefficients are negative, and the one which is statistically significant (the CSP $\mathrm{x}$ troop strength interaction in column (6)) is negative as predicted. The ideal measure of $m$ would somehow average troop density over physical area and population, so a rough averaging of the three precisely estimated negative coefficients in the left panel with the three estimates on the right (two negative and one imprecisely estimated positive) indicates to us fairly robust evidence of complementarity. Recalling our discussion of the possible endogeneity of both $\mathrm{g}$ and $\mathrm{m}$, since any endogeneity bias (despite our best efforts) would be positive, these estimates, if anything, understate complementarity. This evidence of complementarity between development spending and troop strength is illustrated in Figure 4, which plots the predicted marginal effects estimated for small and large CERP (in a combined regression) according to the number of battalions present. Spending becomes more violence-reducing as the number of battalions per district increases. The density of battalions is also plotted in a rug plot, to illustrate the predicted effect for a typical district.

A final testable implication of the model concerns the role of development expertise. Here our interest is in distinguishing the mechanism in the model -which relies on delivering a service, $g$, of value to the community, from a class of "opportunity cost" models that inject wages and employment into the community regardless of whether a service of value is generated. ${ }^{13}$ In other words, for a

\footnotetext{
13 Berman et al (2012) distinguishes between these arguments in the context of an omnibus model.
} 
program to be successful at reducing violence, it must be a development success as well, by delivering desired services to community members. ${ }^{14}$

We test the hypothesis that expertise matters by examining the interaction of spending in the three programs with the presence of a Provincial Reconstruction Team (PRT) in the district. Our working assumptions is that when programs are informed by development experts they are more likely to involve consultation with the community on their requested projects, and will be better designed and implemented to effectively meet the community's request. Formally, our hypothesis is that the coefficient $\gamma_{2}$ on the interaction term of $g$ and PRT is negative, where PRT is a binary indicator.

$$
\begin{aligned}
v_{i, t}-v_{i, t-1} & =\beta_{1}\left(g_{i, t}-g_{i, t-1}\right)+\beta_{2}\left(m_{i, t}-m_{i, t-1}\right)+\beta_{3}\left(v_{i, t-1}-v_{i, t-2}\right) \\
+ & \beta_{4}\left(P R T_{i, t}-P R T_{i, t-1}\right)+\gamma_{2}\left(g_{i, t}-g_{i, t-1}\right)\left(P R T_{i, t}-P R T_{i, t-1}\right)+\delta_{t}+\varepsilon_{i, t} .
\end{aligned}
$$

Table 3 reports results. Columns (1) reports the main effect of PRT presence in isolation, which is violence reducing (i.e., negative) but not precisely enough estimated to constitute evidence of effectiveness. Twenty nine percent of the population lived in districts with a US PRT present during the sample period. As in our discussion of $m$ and $g$, endogeneity bias of the PRT coefficient would be away from finding a violence-reducing effect (i.e., positive), if we thought that PRTs were instituted in anticipation of increased $\varepsilon_{i, t}$. (No PRTs are withdrawn during our sample period so inference is entirely based on the first half-year of PRT presence.) Establishing a PRT would often involve assembling a team, assigning them a security detail, and sometimes even creating a separate base -if there was none already available, which would make response within a half year unlikely but not impossible. The reported coefficient is robust to removing the troop strength variable, and the lagged violence measure (not shown). Column (2) reports that the estimated violence-reducing main effect of CERP (in Table 1 ) is robust to adding a PRT indicator.

\footnotetext{
${ }^{14}$ In a more general model with individual community members rather than a representative agent, a program would only have to successfully deliver desired services to individuals most likely to share information with government.
} 
Columns (3), (4), (5) and (6) report our interaction tests. In all cases (CERP, small CERP, large CERP and CSP) the interaction of PRT with development spending yields a negative coefficient, indicating that the violence-reducing effects of these programs are enhanced by PRT presence. Those interactions effects are statistically significant at the $10 \%$ for large CERP, and at the $1 \%$ level for small CERP. Small CERP projects are almost three times as violence-reducing (-.067+-0.36 vs. -.036) when a PRT is present in the district. That pattern of complementarity is illustrated in Figure 5, which shows the increase in violence reduction (the slope) when a PRT is present.

Taking the evidence in Tables 1 - 3 together, we can draw some conclusions. Development spending is most violence-reducing when it is secure, which addresses the puzzle posed by Table 1 by the relative effectiveness of small CERP programs. Development spending is also more violence reducing when it is informed by local development experts. Small projects are more likely to be violence-reducing, which may reflect the fact that they are better informed, or may be due to their lending themselves more readily to conditional implementation. ${ }^{15}$ Conversely, troop strength is more violence-reducing (or at least less violence-increasing, as measured) when small-scale development spending is present. Finally, the data suggest that smaller projects show stronger complementarities with expertise and with security, which may reflect a further complementarity between conditionality and both security on the one hand and expertise on the other.

\section{Conclusion}

Overall the evidence from Iraq suggests that, in accordance with the informationcentric (or "Hearts and Minds") framework laid out, aid spending which is small, conditional, secure, and effective as a development program creates incentives for

\footnotetext{
15 In results not reported we find no statistically significant complementarities between either troop strength or PRTs on the one hand, and any of the other programs measured in Table 1 on the other. We cautiously interpret that as evidence that the conditionality and security that small projects allow is a necessary condition for violence-reduction in development spending.
} 
cooperation with government that large, less secure and less informed projects do not.

More generally, our theoretical perspective suggests a number of practical lessons for aid programs. Complementarity, as illustrated by Figure 3, indicates that a government wishing to suppress violence at minimal cost would mix the use of development efforts and coercive force, rather than exclusively use one or the other. Evidence suggests that most rebel groups recognize that logic and likewise mix governance initiatives with coercion. ${ }^{16}$

These insights are drawn from the U.S. and Coalition experience in Iraq as an occupying force, and then later in support of a domestic government combating a very violent insurgency. Yet based on our experience applying the same model to other fragile environments, we hypothesize that these lessons may well apply more generally to domestic governments or to international assistance to local allies. Sufficient conditions for development assistance to be stability enhancing in places where a rebel of criminal element can capture or destroy projects are apparently these: they should be modest, secure, conditional, and informed by local preferences. Moreover engaging development expertise, rather than simply spending funds, augments the stabilization effect. For instance, keeping development experts hunkered down far from projects sites is unlikely to be violence-reducing. A logical corollary of complementarity between development and security provision is that foreign assistance to governments fighting insurgencies will be more effective when it includes capacity building in both $g$ and $m$. Investing in training security forces is a standard component of "small footprint" intervention, yet governance assistance is typically limited to training for those who will manage government agencies. Our analysis suggests that training those who would implement local service provision may have a greater immediate violence-reduction effect. In the same vein, security forces, once trained, will be more effective if redeployed out of large, insulated bases and instead engaging the local population in a way that complements development efforts.

16 See BSF for discussion. 
Finally, it is worth putting these results in context. Modest, secure, informed and conditional should be thought of as sufficient conditions for violence-reduction. Further research is required to establish where and to what extent they are all necessary. Further research may also reveal the extent to which a mix of capacity building in both coercive and benign governance can generate medium and long run stabilization -beyond a half-year or one year horizon. The iso-stability lines of Figure 3 are drawn for a given set of norms and expectations. As expectations of quality of governance improve, including political development and representation, enhanced legitimacy should improve norms of cooperation with government -rather than with rebels or criminals. That would shift iso-stability lines to lower levels of violence at the same cost to government in the medium and long term, and allow governments (and allies) the option of shifting spending away from coercive force and toward traditional development programs. 
Figure 1: Best Response Functions for Violence and Development Spending

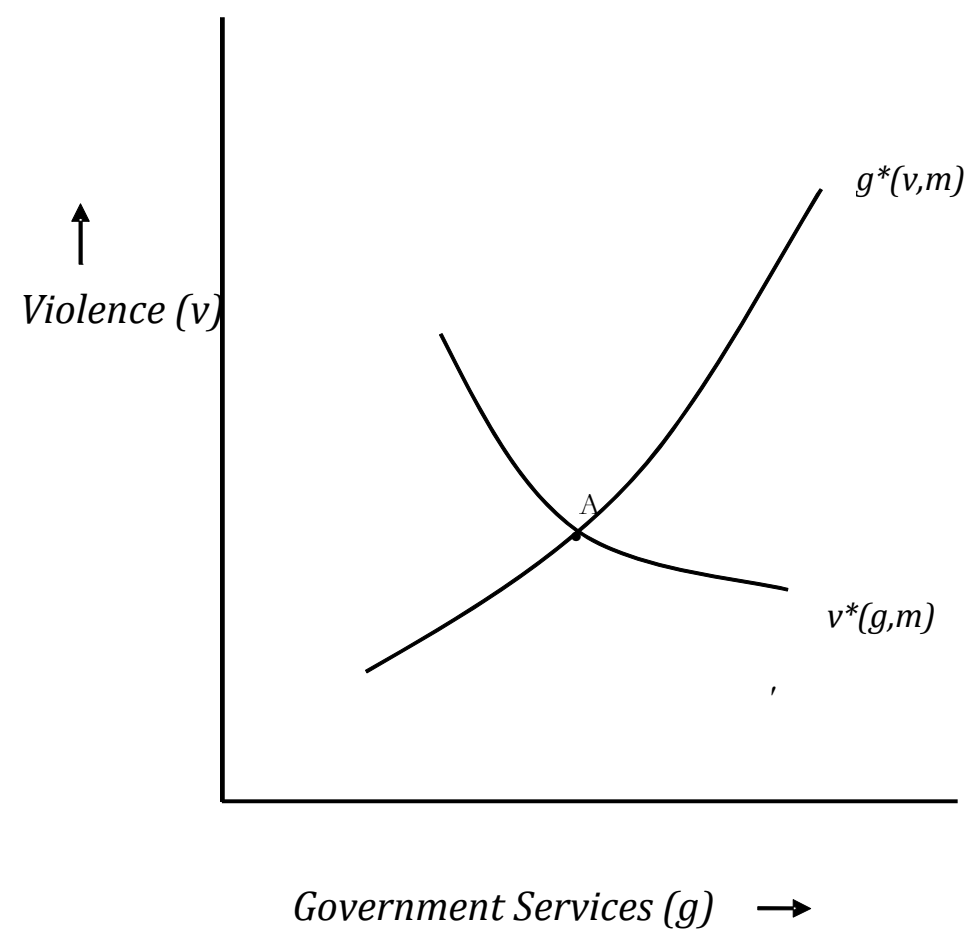


Figure 2a: Services Complement Enforcement

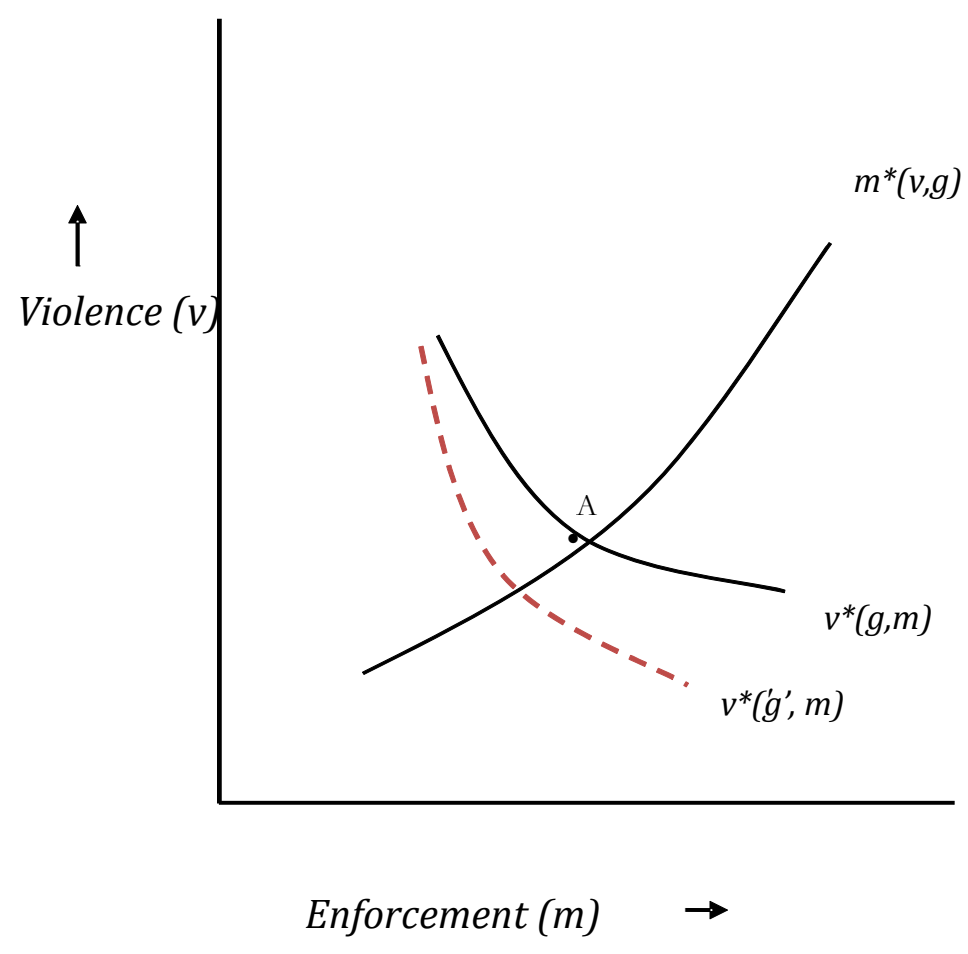

Note: Increasing g to g' makes the slope $\mathrm{dv}^{*} / \mathrm{dm} \mid \mathrm{g}$ more negative. 
Figure 2b: Enforcement Complements Services

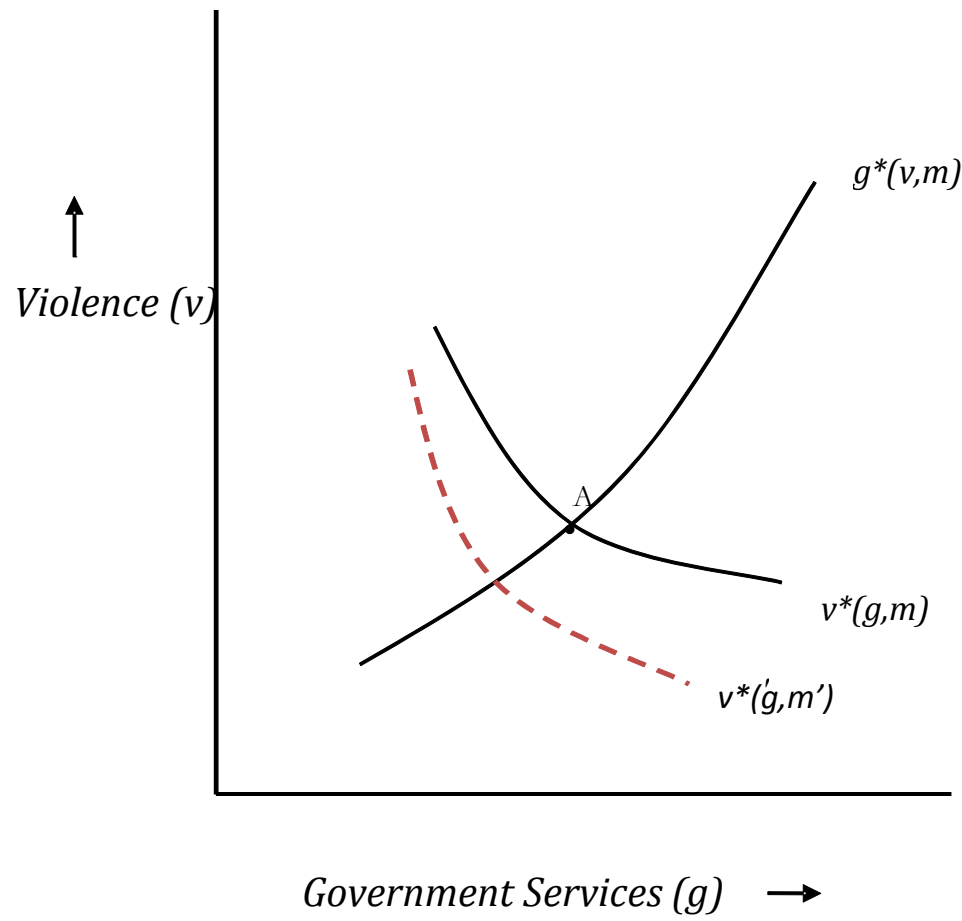

Note: Increasing $\mathrm{m}$ to $\mathrm{m}^{\prime}$ makes the slope $\mathrm{dv}^{*} / \mathrm{dg} \mid \mathrm{m}$ more negative. This is not the same cross-partial effect as in Figure $2 \mathrm{a}$ above, as the derivatives are conditioned on different variables. The change in the slope of $\mathrm{dv}^{*} / \mathrm{dm} \mid \mathrm{g}$ is actually larger. 
Figure 3: Complementarity in Stability Production

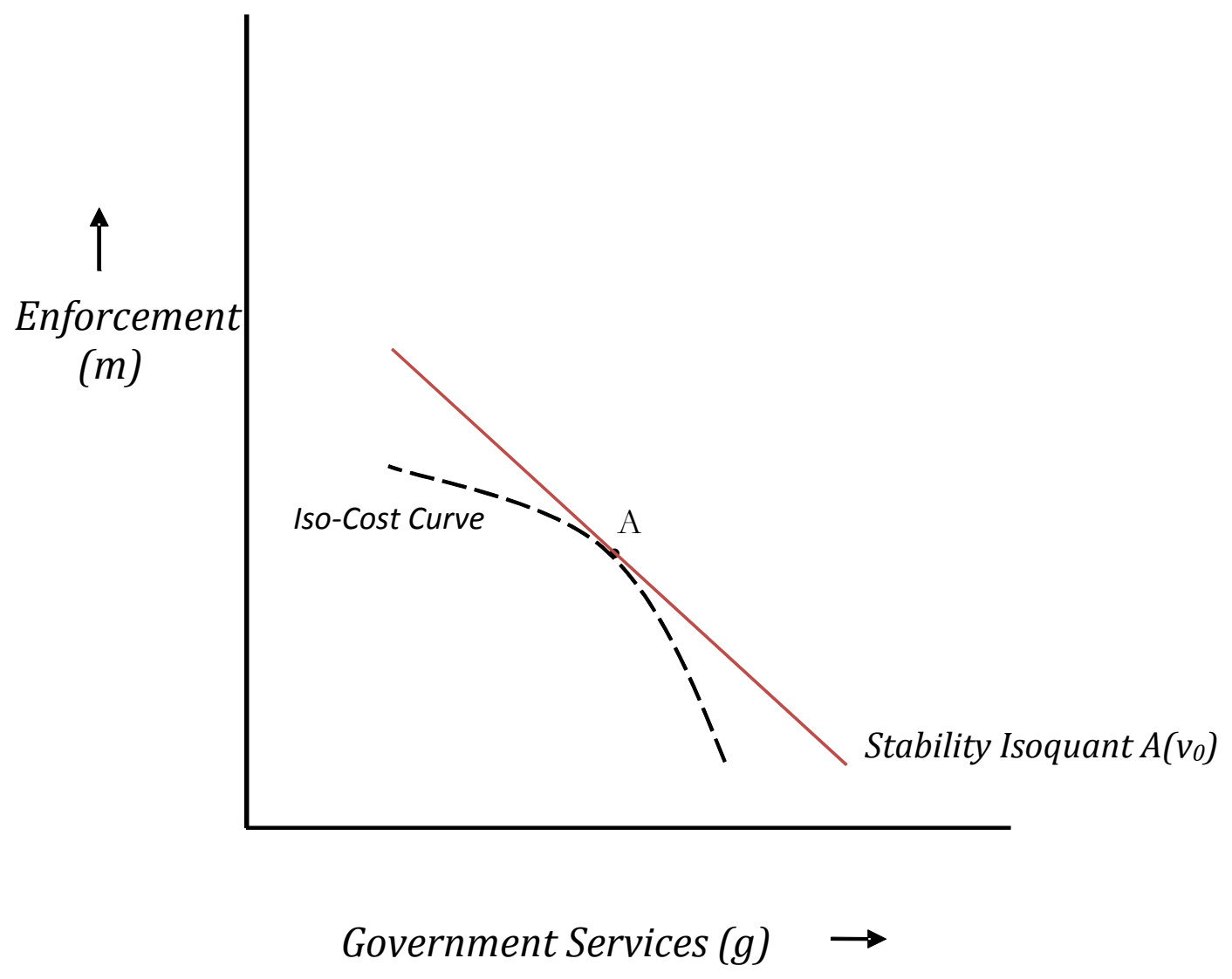




\section{Figure 4: Troop Strength Complements Development Spending}

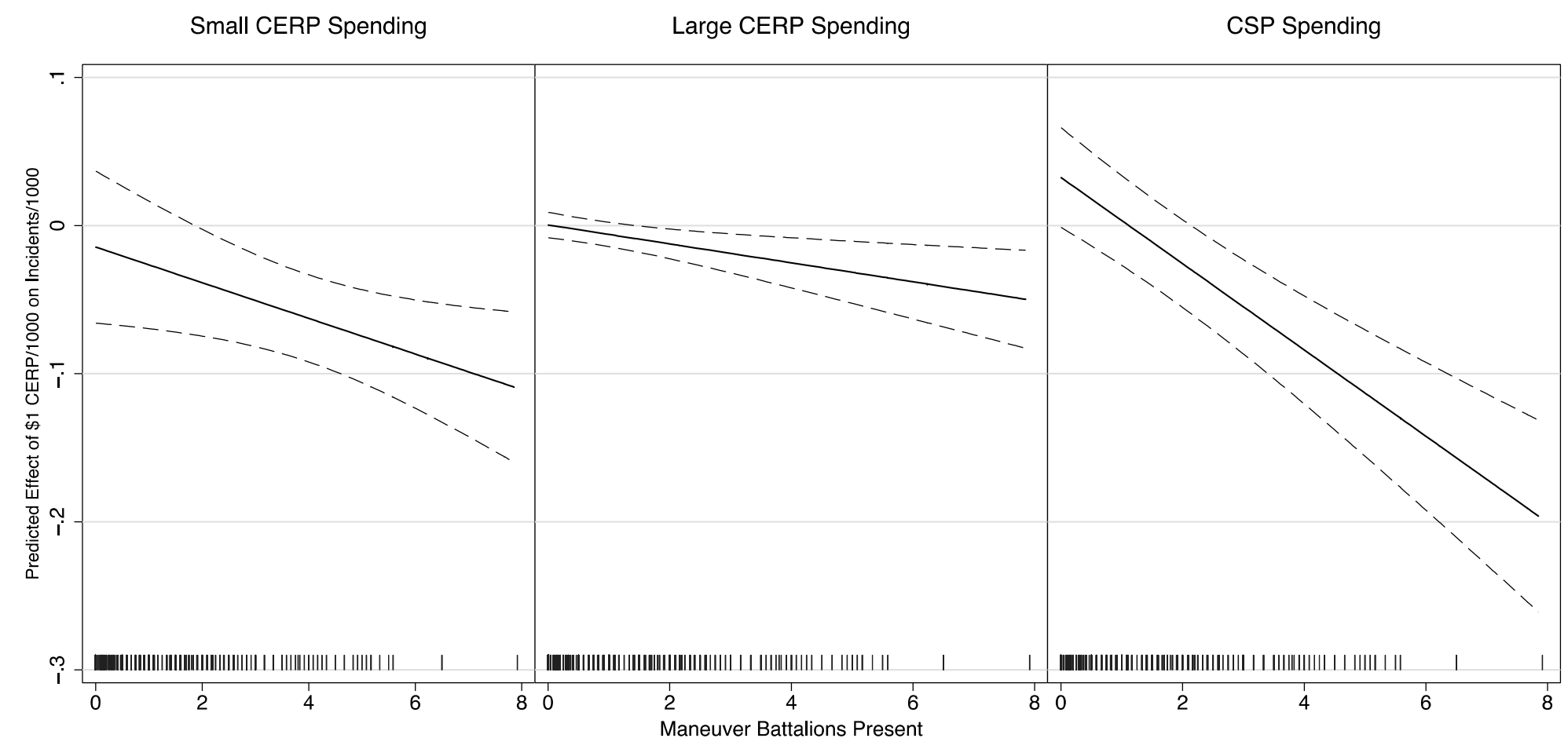


Figure 5: Development Expertise Complements Spending

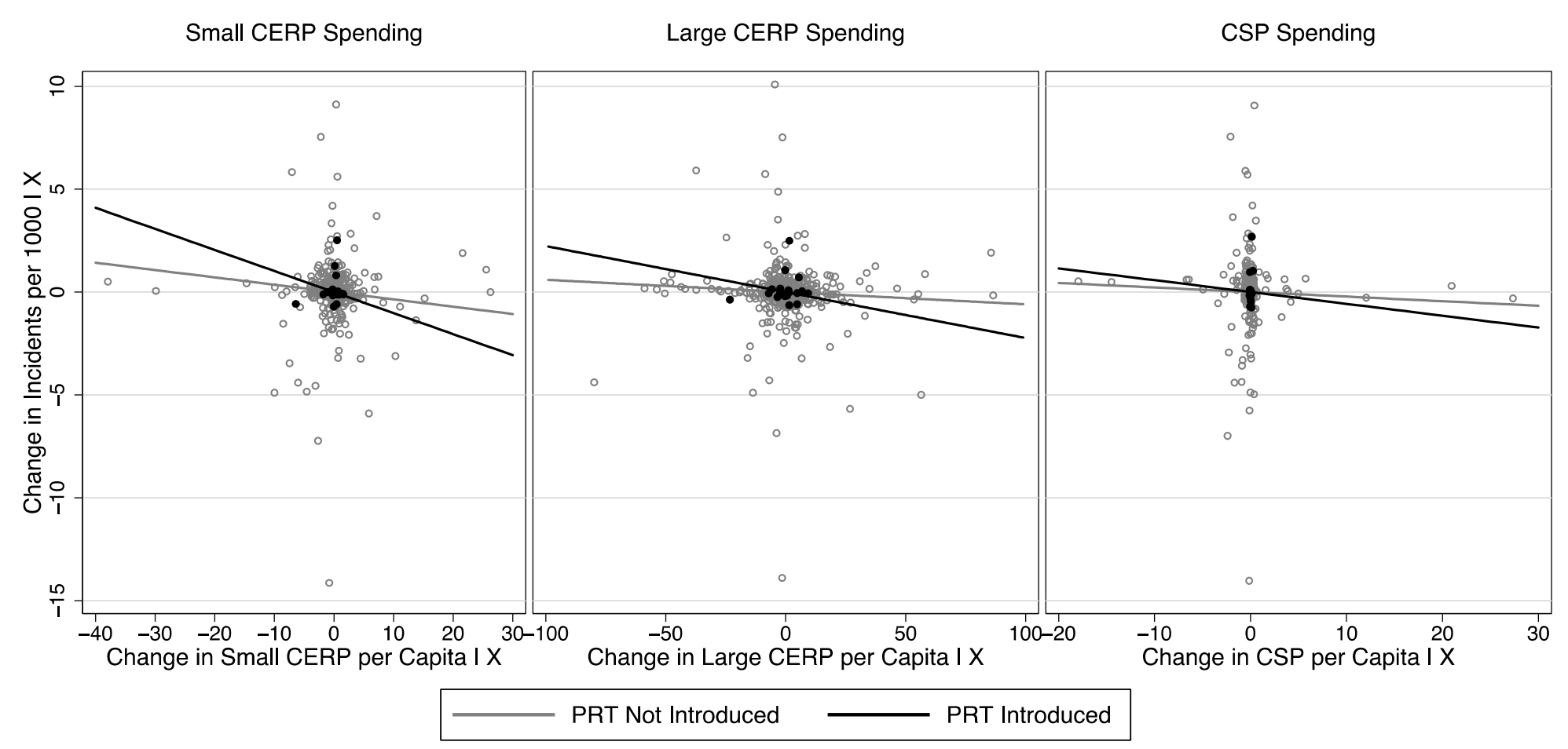


Table 1: Development Programs and Violence Suppression - Alternative Programs

\begin{tabular}{|c|c|c|c|c|c|c|c|c|c|c|}
\hline $\begin{array}{l}\text { Dependent Variable: } \\
\text { Incidents per capita }\end{array}$ & (1) & (2) & (3) & $(4)$ & (5) & (6) & (7) & $(8)$ & (9) & $\begin{array}{c}\text { Variable } \\
\text { Mean }\end{array}$ \\
\hline CERP & $\begin{array}{l}-0.0122^{* *} \\
(0.00548)\end{array}$ & $\begin{array}{l}-0.0122^{* *} \\
(0.00562)\end{array}$ & & & & & & & & $\$ 10.07$ \\
\hline $\mathrm{CERP}<\$ 50 \mathrm{~K}$ & & & $\begin{array}{l}-0.0639^{* * *} \\
(0.0186)\end{array}$ & & & & & & & $\$ 1.32$ \\
\hline CERP $>\$ 50 \mathrm{~K}$ & & & & $\begin{array}{l}-0.0108^{*} \\
(0.00559)\end{array}$ & & & & & & $\$ 8.75$ \\
\hline Non CERP > $\$ 100 \mathrm{~K}$ & & & & & $\begin{array}{l}0.000899 \\
(0.000565)\end{array}$ & & & & & $\$ 33.18$ \\
\hline Non CERP $<\$ 100 \mathrm{~K}$ & & & & & & $\begin{array}{l}0.00636 \\
(0.0228)\end{array}$ & & & & $\$ 0.31$ \\
\hline CSP & & & & & & & $\begin{array}{l}-0.0470^{*} \\
(0.0242)\end{array}$ & & & $\$ 0.44$ \\
\hline CAP & & & & & & & & $\begin{array}{l}-0.0118 \\
(0.0279)\end{array}$ & & $\$ 0.18$ \\
\hline USAID & & & & & & & & & $\begin{array}{l}-0.00248 \\
(0.00334)\end{array}$ & $\$ 12.51$ \\
\hline Troop Strength & & $\begin{array}{l}0.0489 \\
(0.0399)\end{array}$ & $\begin{array}{l}0.0479 \\
(0.0349)\end{array}$ & $\begin{array}{l}0.0451 \\
(0.0400)\end{array}$ & $\begin{array}{l}0.0386 \\
(0.0325)\end{array}$ & $\begin{array}{l}0.0349 \\
(0.0337)\end{array}$ & $\begin{array}{l}0.0466 \\
(0.0328)\end{array}$ & $\begin{array}{l}0.0354 \\
(0.0333)\end{array}$ & $\begin{array}{l}0.0301 \\
(0.0339)\end{array}$ & 1.12 \\
\hline $\begin{array}{l}\text { Lagged Troop } \\
\text { Strength }\end{array}$ & & -0.0255 & 0.0162 & -0.0373 & -0.0411 & -0.0421 & -0.0205 & -0.0424 & -0.0400 & 1.13 \\
\hline & & $(0.0675)$ & $(0.0602)$ & $(0.0704)$ & $(0.0729)$ & $(0.0732)$ & $(0.0705)$ & $(0.0728)$ & $(0.0731)$ & \\
\hline Lagged Incidents & $\begin{array}{l}0.177^{* *} \\
(0.0883)\end{array}$ & $\begin{array}{l}0.173^{*} \\
(0.0893)\end{array}$ & $\begin{array}{l}0.172^{*} \\
(0.0957)\end{array}$ & $\begin{array}{l}0.173^{*} \\
(0.0904)\end{array}$ & $\begin{array}{l}0.173^{*} \\
(0.0973)\end{array}$ & $\begin{array}{l}0.172^{*} \\
(0.0979)\end{array}$ & $\begin{array}{l}0.157 \\
(0.0980)\end{array}$ & $\begin{array}{l}0.171^{*} \\
(0.0971)\end{array}$ & $\begin{array}{l}0.172^{*} \\
(0.0969)\end{array}$ & 0.589 \\
\hline Constant & $\begin{array}{l}0.0907^{* *} \\
(0.0436)\end{array}$ & $\begin{array}{l}0.0969 * * \\
(0.0427)\end{array}$ & $\begin{array}{l}0.0720^{*} \\
(0.0376)\end{array}$ & $\begin{array}{l}0.0897^{* *} \\
(0.0416)\end{array}$ & $\begin{array}{l}0.0557 \\
(0.0359)\end{array}$ & $\begin{array}{l}0.0585 \\
(0.0370)\end{array}$ & $\begin{array}{l}0.0604 \\
(0.0364)\end{array}$ & $\begin{array}{l}0.0574 \\
(0.0363)\end{array}$ & $\begin{array}{l}0.0560 \\
(0.0365)\end{array}$ & \\
\hline Observations & 824 & 824 & 824 & 824 & 824 & 824 & 824 & 824 & 824 & \\
\hline R-squared & 0.213 & 0.215 & 0.222 & 0.204 & 0.180 & 0.179 & 0.194 & 0.179 & 0.180 & \\
\hline $\begin{array}{l}\text { Equality with } \\
\text { CERP }<\$ 50 \mathrm{~K} \text { slope } \\
\text { (p value) }\end{array}$ & - & - & - & $.0002^{* * *}$ & $.0002^{* * *}$ & $.002^{* * *}$ & .338 & $.030^{* *}$ & $.0004^{* * *}$ & \\
\hline
\end{tabular}


Table 2: Complementarity of Development Spending with Troop Strength

\begin{tabular}{|c|c|c|c|c|c|c|}
\hline $\begin{array}{l}\text { Dependent } \\
\text { Variable: } \\
\text { Incidents per } \\
\text { capita }\end{array}$ & (1) & $\begin{array}{c}\text { (2) } \\
\text { Troop Levels }\end{array}$ & (3) & (4) & $\begin{array}{c}(5) \\
\text { Troops per c }\end{array}$ & apita \\
\hline CERP $<\$ 50 \mathrm{~K}$ & $\begin{array}{l}-0.0145 \\
(0.0262)\end{array}$ & & & $\begin{array}{l}-0.0447^{* * *} \\
(0.0157)\end{array}$ & & \\
\hline $\begin{array}{l}\text { CERP }<\$ 50 \mathrm{~K} x \\
\text { Troops }\end{array}$ & $\begin{array}{l}-0.0120^{* *} \\
(0.00542)\end{array}$ & & & $\begin{array}{l}-0.0140 \\
(0.0155)\end{array}$ & & \\
\hline CERP > \$50K & & $\begin{array}{l}0.000353 \\
(0.00438)\end{array}$ & & & $\begin{array}{l}-0.0122^{* *} \\
(0.00565)\end{array}$ & \\
\hline $\begin{array}{l}\text { CERP }>\$ 50 \mathrm{~K} x \\
\text { Troops }\end{array}$ & & $\begin{array}{l}-0.00639^{* * *} \\
(0.00228)\end{array}$ & & & $\begin{array}{l}0.00120 \\
(0.000752)\end{array}$ & \\
\hline CSP & & & $\begin{array}{l}0.0325^{*} \\
(0.0172)\end{array}$ & & & $\begin{array}{l}0.0146 \\
(0.0187)\end{array}$ \\
\hline CSP x Troops & & & $\begin{array}{l}-0.0291^{* * *} \\
(0.00480)\end{array}$ & & & $\begin{array}{l}-0.102^{* *} \\
(0.0422)\end{array}$ \\
\hline Troops & $\begin{array}{l}0.0655^{*} \\
(0.0389)\end{array}$ & $\begin{array}{l}0.136^{* *} \\
(0.0517)\end{array}$ & $\begin{array}{l}0.0746^{*} \\
(0.0393)\end{array}$ & $\begin{array}{l}0.229 \\
(0.284)\end{array}$ & $\begin{array}{l}0.112 \\
(0.270)\end{array}$ & $\begin{array}{l}0.245 \\
(0.252)\end{array}$ \\
\hline Lagged Troops & $\begin{array}{l}0.0106 \\
(0.0607)\end{array}$ & $\begin{array}{l}-0.0335 \\
(0.0684)\end{array}$ & $\begin{array}{l}-0.0164 \\
(0.0693)\end{array}$ & $\begin{array}{l}-0.493 \\
(0.370)\end{array}$ & $\begin{array}{l}-0.537 \\
(0.370)\end{array}$ & $\begin{array}{l}-0.613^{*} \\
(0.355)\end{array}$ \\
\hline Lagged incidents & $\begin{array}{l}0.188^{*} \\
(0.0992)\end{array}$ & $\begin{array}{l}0.190^{* *} \\
(0.0934)\end{array}$ & $\begin{array}{l}0.162 \\
(0.0993)\end{array}$ & $\begin{array}{l}0.181^{*} \\
(0.0998)\end{array}$ & $\begin{array}{l}0.177^{*} \\
(0.0940)\end{array}$ & $\begin{array}{l}0.165 \\
(0.103)\end{array}$ \\
\hline Constant & $\begin{array}{l}0.0669^{*} \\
(0.0382)\end{array}$ & $\begin{array}{l}0.0842^{* *} \\
(0.0380)\end{array}$ & $\begin{array}{l}0.0629^{*} \\
(0.0364)\end{array}$ & $\begin{array}{l}0.0615 \\
(0.0412)\end{array}$ & $\begin{array}{l}0.0832^{*} \\
(0.0460)\end{array}$ & $\begin{array}{l}0.0519 \\
(0.0399)\end{array}$ \\
\hline Observations & 824 & 824 & 824 & 824 & 824 & 824 \\
\hline R-squared & 0.231 & 0.231 & 0.217 & 0.234 & 0.223 & 0.225 \\
\hline
\end{tabular}

Notes: An observation is a district $(\mathrm{N}=103) \mathrm{x}$ half year. District Karkh is excluded as national CSP programs are confounded with local there. Incidents are measured per 1000 population. Their mean is 0.587. Troop strength is measured in battalions per district in the left panel (columns (1)-(3)) with mean 1.12. Troop strength is measured in battalions per $100 \mathrm{~K}$ population in the right panel (columns (4)-(6)) with mean of 0.22 . Regressions are weighted by population and include year effects, and Sunni vote-year interactions. ${ }^{* * *} \mathrm{p}<0.01,{ }^{* *} \mathrm{p}<0.05,{ }^{*} \mathrm{p}<0.1$. Standard errors are clustered at the district level. 
Table 3: Expertise Complements Development Programs

\begin{tabular}{|c|c|c|c|c|c|c|c|}
\hline $\begin{array}{l}\text { Dependent } \\
\text { Variable: } \\
\text { Incidents }\end{array}$ & (1) & (2) & (3) & (4) & (5) & (6) & $\begin{array}{c}\text { Variable } \\
\text { Mean }\end{array}$ \\
\hline CERP & & $\begin{array}{c}-0.0122^{* *} \\
(0.00561)\end{array}$ & $\begin{array}{l}-0.00672 \\
(0.00472)\end{array}$ & & & & $\$ 10.07$ \\
\hline CERP x PRT & & & $\begin{array}{l}-0.0172^{*} \\
(0.00912)\end{array}$ & & & & $\$ 3.84$ \\
\hline CERP $<\$ 50 \mathrm{~K}$ & & & & $\begin{array}{l}-0.0357^{* *} \\
(0.0174)\end{array}$ & & & $\$ 1.32$ \\
\hline CERP $<\$ 50 \mathrm{~K} x$ & & & & & & & \\
\hline PRT & & & & $\begin{array}{l}-0.0667^{* * *} \\
(0.0176)\end{array}$ & & & $\$ 0.42$ \\
\hline CERP $>\$ 50 \mathrm{~K}$ & & & & & $\begin{array}{l}-0.00594 \\
(0.00476)\end{array}$ & & $\$ 8.75$ \\
\hline CERP $>\$ 50 \mathrm{~K} x$ & & & & & & & \\
\hline PRT & & & & & $\begin{array}{l}-0.0164^{*} \\
(0.00958)\end{array}$ & & $\$ 3.42$ \\
\hline CSP & & & & & & $\begin{array}{l}-0.0222 \\
(0.0152)\end{array}$ & $\$ 0.44$ \\
\hline CSP x PRT & & & & & & $\begin{array}{l}-0.0354 \\
(0.0397)\end{array}$ & $\$ 0.31$ \\
\hline PRT & $\begin{array}{l}-0.0136 \\
(0.0829)\end{array}$ & $\begin{array}{l}-0.0228 \\
(0.0822)\end{array}$ & $\begin{array}{l}0.137 \\
(0.131)\end{array}$ & $\begin{array}{l}0.0750 \\
(0.0885)\end{array}$ & $\begin{array}{l}0.109 \\
(0.121)\end{array}$ & $\begin{array}{l}-0.00337 \\
(0.0840)\end{array}$ & 0.29 \\
\hline Troops & $\begin{array}{l}0.0345 \\
(0.0327)\end{array}$ & $\begin{array}{l}0.0480 \\
(0.0400)\end{array}$ & $\begin{array}{l}0.0751^{*} \\
(0.0449)\end{array}$ & $\begin{array}{l}0.0731^{*} \\
(0.0414)\end{array}$ & $\begin{array}{l}0.0638 \\
(0.0410)\end{array}$ & $\begin{array}{l}0.0496 \\
(0.0338)\end{array}$ & 0.22 \\
\hline Lagged Troops & $\begin{array}{l}-0.0424 \\
(0.0741)\end{array}$ & $\begin{array}{l}-0.0260 \\
(0.0687)\end{array}$ & $\begin{array}{l}-0.0168 \\
(0.0669)\end{array}$ & $\begin{array}{l}0.00877 \\
(0.0613)\end{array}$ & $\begin{array}{l}-0.0286 \\
(0.0703)\end{array}$ & $\begin{array}{l}-0.0185 \\
(0.0731)\end{array}$ & 0.23 \\
\hline Lagged Incidents & $\begin{array}{l}0.171^{*} \\
(0.0971)\end{array}$ & $\begin{array}{l}0.173^{*} \\
(0.0895)\end{array}$ & $\begin{array}{l}0.154^{*} \\
(0.0889)\end{array}$ & $\begin{array}{l}0.170^{*} \\
(0.0964)\end{array}$ & $\begin{array}{l}0.155^{*} \\
(0.0903)\end{array}$ & $\begin{array}{l}0.156 \\
(0.0986)\end{array}$ & 0.59 \\
\hline Constant & $\begin{array}{l}0.0594^{*} \\
(0.0328)\end{array}$ & $\begin{array}{l}0.100^{* *} \\
(0.0382)\end{array}$ & $\begin{array}{l}0.0887^{* *} \\
(0.0354)\end{array}$ & $\begin{array}{l}0.0701^{* *} \\
(0.0316)\end{array}$ & $\begin{array}{l}0.0838^{* *} \\
(0.0353)\end{array}$ & $\begin{array}{l}0.0614^{*} \\
(0.0335)\end{array}$ & \\
\hline Observations & 824 & 824 & 824 & 824 & 824 & 824 & \\
\hline R-squared & 0.179 & 0.216 & 0.233 & 0.236 & 0.217 & 0.196 & \\
\hline
\end{tabular}

Notes: An observation is a district $(\mathrm{N}=103) \mathrm{x}$ half year. District Karkh is excluded as national CSP programs are confounded with local there. Means are for levels (NT=927) though regressions are estimated in first differences ( $\mathrm{NT}=824)$. Incidents are measured per 1000 population. Their mean is 0.587 . Troop strength is measured in battalions per district. Regressions are weighted by population and include year effects, and Sunni vote-year interactions. ${ }^{* * *} \mathrm{p}<0.01,{ }^{* *} \mathrm{p}<0.05,{ }^{*} \mathrm{p}<0.1$. Standard errors are clustered at the district level. 


\section{References}

Berman, Eli, Joseph Felter, Ethan Kapstein and Erin Troland. 2012. "Predation, Economic Activity and Violence: Evidence from the Philippines." NBER WP \#18375.

Berman, Eli, Jacob N. Shapiro and Joseph H. Felter. 2011. "Can Hearts and Minds be Bought? The Economics of Counterinsurgency in Iraq," Journal of Political Economy, 119(4).

Berrebi, Claude and Sarah Olmstead. 2011. "Establishing Favorable Economic Conditions," in Paul K., Davis (ed.) Dilemmas of Intervention: Social Science for Stabilization and Reconstruction, RAND, Santa Monica.

Blattman, Christopher and Edward Miguel. 2010. "Civil War." Journal of Economic Literature, 48(1).

Gradstein, Mark. 2004. "Governance and Growth," Journal of Development Economics, 73.

Guillaumont, Lisa, and Patrick Chauvet. 2003."Aid and Growth Revisited: Policy, Economic Vulnerability." CERDI.

Collier, Paul and Anke Hoeffler. 2004. "Greed and Grievance in Civil War" Oxford Economic Papers, 56(4).

Crost, Benjamin, Joseph H. Felter and Patrick Johnston. 2012. "Aid Under Fire: Development Projects and Civil Conflict," U. of Colorado, Denver mimeo, January.

Flores, Thomas Edward, and Irfan Nooruddin. 2009. "Financing the Peace: Evaluating World Bank Post-Conflict Assistance Programs." Review of International Organizations 4(1): 1-27.

Guillaumont, Patrick and Rachid Laajaj. 2006. "When instability increases the effectiveness of aid projects," Policy Research Working Paper Series \#4034. The World Bank.

Hirshleifer, Jack. 1989. "Conflict and Rent-Seeking Success Functions: Ratio vs. Difference Models of Relative Success." Public Choice, 63.

Lee, Carrie, "Battalion Dataset Codebook," Stanford University, September 2011.

Lee, Carrie, "Holding Hearts and Minds: The Effect of Boots on the Ground in Iraq," Stanford University, March 2012.

Nielsen, Richard, A. Michael G. Findley, Zachary S. Davis, Tara Candland, Daniel L. Nielson. 2011. "Foreign Aid Shocks as a Cause of Violent Armed Conflict," American Journal of Political Science, 55(2).

Mas-Collel, Andreu, Michael D. Whinston and Jerry R. Green. 1995. Microeconomic Theory, New York: Oxford.

Svensson , Jakob. 2003. "Why conditional aid does not work and what can be done about it?." Journal of Development Economics, 70.

U.S. Agency for International Development, "Where Does the Money Go?" (spreadsheet), http://www.usaid.gov/results-and-data/budgetspending/where-does-money-go, downloaded January 9, 2013.

U.S Army. 2007. Field Manual 3-24, Counterinsurgency Field Manual. Chicago: Univ. of Chicago Press. 
Vanden Eynde, Oliver. 2012. “Targets of Violence: Evidence from India's Naxalite Conflict," Paris School of Economics, mimeo.

World Bank, 2011. World Development Report 2011: Conflict, Security and Development. World Bank Group, Washington DC. 


\section{Appendix: Proofs of Propositions 1 and 2}

The proofs of both propositions rely on partial differentiation of the slopes of the optimal response functions of $\mathrm{R}$ in choosing $v^{*}$.

Proposition 1: $d\left(\frac{\partial v^{*}}{\partial m} \mid g\right) / d g<0$

Proof: $\frac{\partial v^{*}}{\partial m}\left|g=-\frac{\partial^{2} E U_{R}}{\partial v \partial m}\right| g / \frac{\partial^{2} E U_{R}}{\partial v^{2}}$ and by the implicit function theorem,

$$
=-\left[-\mathrm{A}^{\prime}(v)\left(g+v-n_{L}\right) f \mathrm{~h}^{\prime}(m)-\mathrm{A}(v) f \mathrm{~h}^{\prime}(m)\right] /\left\{\mathrm{A}^{\prime \prime}(v)\left[1-p^{*}\right]-2 \mathrm{~A}^{\prime}(v) f \mathrm{~h}(m)-\mathrm{B}^{\prime \prime}(v)\right\} .
$$

Denoting the numerator $\Delta$ and the denominator $\Omega$,

$d\left(\frac{\partial v^{*}}{\partial m} \mid g\right) /_{d g}=\frac{\Delta^{\prime} \Omega-\Omega^{\prime} \Delta}{\Omega^{2}}<0$,

since $\Delta^{\prime}=\mathrm{A}^{\prime}(v) f \mathrm{~h}^{\prime}(m)>0, \Omega<0, \Delta>0$, and $\Omega^{\prime}=-\mathrm{A}^{\prime \prime}(v) f \mathrm{~h}(m)>0$, and $\Omega^{2}>0$.

Proposition 2: : $d\left(\left.\frac{\partial v^{*}}{\partial g}\right|_{m}\right) /_{d m}<0$.

Proof: $\left.\frac{\partial v^{*}}{\partial g}\right|_{m}=-\left.\frac{\partial^{2} E U_{R}}{\partial v \partial g}\right|_{m} / \frac{\partial^{2} E U_{R}}{\partial v^{2}}$ by the implicit function theorem,

$$
=-(-) \mathrm{A}^{\prime}(v) f \mathrm{~h}(m) /\left\{\mathrm{A}^{\prime \prime}(v)\left[1-p^{*}\right]-2 \mathrm{~A}^{\prime}(v) f \mathrm{~h}(m)-\mathrm{B}^{\prime \prime}(v)\right\} .
$$

Denoting the numerator $\Delta$ and the denominator $\Omega$,

$$
\begin{aligned}
& d\left(\frac{\partial v^{*}}{\partial g} \mid m\right){ }_{d m}=\frac{\Delta^{\prime} \Omega-\Omega^{\prime} \Delta}{\Omega^{2}} . \\
& \Delta^{\prime} \Omega-\Omega^{\prime} \Delta=\mathrm{A}^{\prime}(v) f \mathrm{~h}^{\prime}(m)\left\{\mathrm{A}^{\prime \prime}(v)\left[1-p^{*}\right]-2 \mathrm{~A}^{\prime}(v) f \mathrm{~h}(m)-\mathrm{B}^{\prime \prime}(v)\right\}
\end{aligned}
$$




$$
\begin{aligned}
& -\mathrm{A}^{\prime}(v) f \mathrm{~h}(m)\left\{-\mathrm{A}^{\prime \prime}(v)\left(g+v-n_{\mathrm{L}}\right) f \mathrm{~h}^{\prime}(m)-2 \mathrm{~A}^{\prime}(v) f \mathrm{~h}^{\prime}(m)\right\} \\
& =\mathrm{A}^{\prime}(v) f \mathrm{~h}^{\prime}(m) \mathrm{A}^{\prime \prime}(v)\left[1-p^{*}\right]-2 \mathrm{~A}^{\prime}(v) f \mathrm{~h}^{\prime}(m) \mathrm{A}^{\prime}(v) f \mathrm{~h}(m)-\mathrm{A}^{\prime}(v) f \mathrm{~h}^{\prime}(m) \mathrm{B}^{\prime \prime}(v) \\
& +\mathrm{A}^{\prime}(v) f \mathrm{~h}(m) \mathrm{A}^{\prime \prime}(v)\left(g+v-n_{\mathrm{L}}\right) f \mathrm{~h}^{\prime}(m)+2 \mathrm{~A}^{\prime}(v) f \mathrm{~h}(m) \mathrm{A}^{\prime}(v) f \mathrm{~h}^{\prime}(m) .
\end{aligned}
$$

The second and fifth terms cancel. The other three terms are negative (since $\mathrm{A}^{\prime \prime}(\nu)<0$ ), so the expression is negative. $\Omega^{2}>0$, which implies that $\frac{\Delta^{\prime} \Omega-\Omega^{\prime} \Delta}{\Omega^{2}}<0$. 
Appendix Table 1: Summary Statistics (Changes)

\begin{tabular}{|c|c|c|c|c|c|c|}
\hline & Observations & Weight & Mean & Std. Dev. & Min & Max \\
\hline Incidents & 927 & 246754372 & -0.0025253 & 0.7192714 & -14.30548 & 9.791145 \\
\hline Lagged Incidents & 824 & 221459256 & 0.0246278 & 0.7529446 & -14.30548 & 9.791145 \\
\hline CERP & 927 & 246754372 & 0.8975824 & 11.75703 & -252.7587 & 264.7626 \\
\hline $\mathrm{CERP}<\$ 50 \mathrm{~K}$ & 927 & 246754372 & 0.0978531 & 2.637987 & -43.8516 & 34.17538 \\
\hline CERP $>\$ 50 \mathrm{~K}$ & 927 & 246754372 & 0.7997293 & 10.81382 & -252.7587 & 302.5766 \\
\hline Non CERP & 927 & 246754372 & -2.044234 & 79.77404 & -10735.33 & 892.7099 \\
\hline Non Cerp $<\$ 100,000$ & 927 & 246754372 & -0.1364265 & 1.977181 & -45.27344 & 14.09699 \\
\hline Non CERP $>\$ 100,000$ & 927 & 246754372 & -1.907807 & 79.62294 & -10724.78 & 892.3289 \\
\hline CAP & 927 & 246754372 & 0.0339391 & 0.6284991 & -8.891963 & 16.47236 \\
\hline $\operatorname{CSP}$ & 927 & 246754372 & 0.0539443 & 2.029424 & -18.23231 & 29.00582 \\
\hline USAID & 927 & 246754372 & -1.833554 & 72.81415 & -10757.88 & 66.87154 \\
\hline PRT & 927 & 246754372 & 0.0503777 & 0.2188411 & 0 & 1 \\
\hline Troop Strength & 927 & 246754372 & -0.008259 & 0.6462308 & -3 & 2.333333 \\
\hline Lagged Troop Strength & 824 & 221459256 & -0.0033438 & 0.645426 & -3 & 2.333333 \\
\hline CERP x Troop Strength & 927 & 246754372 & 1.71061 & 37.70935 & -512.5932 & 725.2957 \\
\hline CERP $<\$ 50,000 \times$ Troop Strength & 927 & 246754372 & 0.1375683 & 12.52012 & -165.8702 & 93.96977 \\
\hline CERP $>\$ 50,000 \times$ Troop Strength & 927 & 246754372 & 1.573042 & 29.48188 & -482.8429 & 729.1677 \\
\hline CSP x Troop Strength & 927 & 246754372 & 0.0700144 & 7.186853 & -74.87498 & 77.8888 \\
\hline $\mathrm{CERP}<\$ 50,000 \times \mathrm{PRT}$ & 927 & 246754372 & 0.0390839 & 1.764686 & -25.60038 & 18.19453 \\
\hline CERP $>\$ 50,000 \times$ PRT & 927 & 246754372 & 0.4654902 & 6.177386 & -80.17256 & 58.67921 \\
\hline CSP $x$ PRT & 927 & 246754372 & 0.0228998 & 1.721804 & -13.36795 & 14.78048 \\
\hline
\end{tabular}

Notes: An observation is a district $(\mathrm{N}=103) \mathrm{x}$ half year. District Karkh is excluded as national CSP programs are confounded with local there. Means are in changes, weighted by population. Regressions include NT=824 observations. Incidents are measured per 1000 population, spending variables are per capita. Troop strength is measured in battalions per district. 
Appendix Table 2: Robustness of Table 1 results to inclusion of per capita troop strength

\begin{tabular}{|c|c|c|c|c|c|c|c|c|c|}
\hline $\begin{array}{l}\text { Dependent Variable: } \\
\text { Incidents per capita }\end{array}$ & $(1)$ & $(2)$ & $(3)$ & (4) & (5) & (6) & (7) & $(8)$ & $(9)$ \\
\hline CERP & $\begin{array}{l}-0.0122^{* *} \\
(0.00548)\end{array}$ & $\begin{array}{l}-0.0116^{* *} \\
(0.00560)\end{array}$ & & & & & & & \\
\hline CERP $<\$ 50 \mathrm{~K}$ & & & $\begin{array}{c}-0.0569^{* * *} \\
(0.0197)\end{array}$ & & & & & & \\
\hline CERP > $\$ 50 \mathrm{~K}$ & & & & $\begin{array}{l}-0.0103^{*} \\
(0.00557)\end{array}$ & & & & & \\
\hline Non CERP $<\$ 100 \mathrm{~K}$ & & & & & $\begin{array}{l}0.00436 \\
(0.0213)\end{array}$ & & & & \\
\hline Non CERP $>\$ 100 \mathrm{~K}$ & & & & & & $\begin{array}{c}0.000677 \\
(0.000611)\end{array}$ & & & \\
\hline CSP & & & & & & & $\begin{array}{l}-0.0443^{*} \\
(0.0227)\end{array}$ & & \\
\hline CAP & & & & & & & & $\begin{array}{l}-0.0151 \\
(0.0281)\end{array}$ & \\
\hline USAID & & & & & & & & & $\begin{array}{c}-0.00223 \\
(0.00295)\end{array}$ \\
\hline Troop Strength Per Capita & & $\begin{array}{c}0.207 \\
(0.265)\end{array}$ & $\begin{array}{c}0.165 \\
(0.272)\end{array}$ & $\begin{array}{c}0.200 \\
(0.263)\end{array}$ & $\begin{array}{c}0.157 \\
(0.249)\end{array}$ & $\begin{array}{c}0.161 \\
(0.248)\end{array}$ & $\begin{array}{c}0.179 \\
(0.250)\end{array}$ & $\begin{array}{c}0.159 \\
(0.250)\end{array}$ & $\begin{array}{c}0.150 \\
(0.250)\end{array}$ \\
\hline Lagged Troop Strength Per Capita & & $\begin{array}{c}-0.534 \\
(0.364)\end{array}$ & $\begin{array}{c}-0.472 \\
(0.361)\end{array}$ & $\begin{array}{l}-0.569 \\
(0.359)\end{array}$ & $\begin{array}{l}-0.617^{*} \\
(0.349)\end{array}$ & $\begin{array}{l}-0.610^{*} \\
(0.349)\end{array}$ & $\begin{array}{c}-0.583 \\
(0.354)\end{array}$ & $\begin{array}{l}-0.619 * \\
(0.348)\end{array}$ & $\begin{array}{l}-0.612^{*} \\
(0.349)\end{array}$ \\
\hline Lagged Incidents & $\begin{array}{c}0.177^{* *} \\
(0.0883)\end{array}$ & $\begin{array}{c}0.177^{*} \\
(0.0938)\end{array}$ & $\begin{array}{c}0.178^{*} \\
(0.1000)\end{array}$ & $\begin{array}{c}0.176^{*} \\
(0.0948)\end{array}$ & $\begin{array}{c}0.177^{*} \\
(0.102)\end{array}$ & $\begin{array}{l}0.177^{*} \\
(0.101)\end{array}$ & $\begin{array}{c}0.163 \\
(0.103)\end{array}$ & $\begin{array}{c}0.177^{*} \\
(0.101)\end{array}$ & $\begin{array}{l}0.177^{*} \\
(0.101)\end{array}$ \\
\hline Constant & $\begin{array}{l}0.0907 * * \\
(0.0436)\end{array}$ & $\begin{array}{c}0.0869 * \\
(0.0465)\end{array}$ & $\begin{array}{c}0.0627 \\
(0.0412)\end{array}$ & $\begin{array}{l}0.0805^{*} \\
(0.0454)\end{array}$ & $\begin{array}{c}0.0508 \\
(0.0405)\end{array}$ & $\begin{array}{c}0.0485 \\
(0.0394)\end{array}$ & $\begin{array}{c}0.0520 \\
(0.0404)\end{array}$ & $\begin{array}{c}0.0500 \\
(0.0398)\end{array}$ & $\begin{array}{c}0.0493 \\
(0.0400)\end{array}$ \\
\hline Observations & 824 & 824 & 824 & 824 & 824 & 824 & 824 & 824 & 824 \\
\hline R-squared & 0.213 & 0.231 & 0.233 & 0.221 & 0.198 & 0.199 & 0.212 & 0.198 & 0.199 \\
\hline
\end{tabular}

Notes: An observation is a district $(\mathrm{N}=103) \mathrm{x}$ half year. District Karkh is excluded as national CSP programs are confounded with local there. Means are for levels (NT=927) though regressions are estimated in first differences (NT=824). Incidents are measured per 1000 population. Their mean is 0.587 . Troop strength is measured in battalions per district per capita. Regressions are weighted by population and include year effects, and Sunni vote-year interactions. ${ }^{* * *} \mathrm{p}<0.01,{ }^{* *} \mathrm{p}<0.05, * \mathrm{p}<0.1$. Standard errors are clustered at the district level. 


\section{Appendix Table 3: Robustness of Table 3 (PRTs and Spending)}

\section{to inclusion of per capita troop strength}

\begin{tabular}{|c|c|c|c|c|c|}
\hline $\begin{array}{l}\text { Dependent Variable: } \\
\text { Incidents }\end{array}$ & (1) & (2) & (3) & (4) & (5) \\
\hline CERP & & $\begin{array}{r}-0.0116^{* *} \\
(0.00559)\end{array}$ & & & \\
\hline CERP $<\$ 50 \mathrm{~K}$ & & & $\begin{array}{l}-0.0266 \\
(0.0168)\end{array}$ & & \\
\hline CERP $<\$ 50 K \times$ PRT & & & $\begin{array}{c}-0.0705^{* * *} \\
(0.0171)\end{array}$ & & \\
\hline CERP $>\$ 50 \mathrm{~K}$ & & & & $\begin{array}{l}-0.00572 \\
(0.00451)\end{array}$ & \\
\hline CERP $>\$ 50 \mathrm{~K} \times \mathrm{PRT}$ & & & & $\begin{array}{l}-0.0155^{*} \\
(0.00931)\end{array}$ & \\
\hline CSP & & & & & $\begin{array}{l}-0.0222 \\
(0.0151)\end{array}$ \\
\hline CSP $\times$ PRT & & & & & $\begin{array}{l}-0.0313 \\
(0.0378)\end{array}$ \\
\hline PRT & $\begin{array}{l}-0.0419 \\
(0.0843)\end{array}$ & $\begin{array}{l}-0.0542 \\
(0.0813)\end{array}$ & $\begin{array}{c}0.0346 \\
(0.0808)\end{array}$ & $\begin{array}{l}0.0649 \\
(0.115)\end{array}$ & $\begin{array}{l}-0.0395 \\
(0.0842)\end{array}$ \\
\hline Troop Strength per Capita & $\begin{array}{l}0.156 \\
(0.250)\end{array}$ & $\begin{array}{l}0.206 \\
(0.265)\end{array}$ & $\begin{array}{l}0.237 \\
(0.266)\end{array}$ & $\begin{array}{c}0.227 \\
(0.278)\end{array}$ & $\begin{array}{l}0.188 \\
(0.252)\end{array}$ \\
\hline Lagged Troop Strength per & & & & & \\
\hline Capita & $\begin{array}{l}-0.621^{*} \\
(0.351)\end{array}$ & $\begin{array}{l}-0.538 \\
(0.366)\end{array}$ & $\begin{array}{l}-0.519 \\
(0.358)\end{array}$ & $\begin{array}{l}-0.559 \\
(0.366)\end{array}$ & $\begin{array}{l}-0.577 \\
(0.359)\end{array}$ \\
\hline Lagged Incidents & $\begin{array}{l}0.176^{*} \\
(0.101)\end{array}$ & $\begin{array}{c}0.176^{*} \\
(0.0942)\end{array}$ & $\begin{array}{l}0.175^{*} \\
(0.100)\end{array}$ & $\begin{array}{c}0.160^{*} \\
(0.0954)\end{array}$ & $\begin{array}{c}0.162 \\
(0.103)\end{array}$ \\
\hline Constant & $\begin{array}{l}0.0564^{*} \\
(0.0338)\end{array}$ & $\begin{array}{c}0.0951^{* *} \\
(0.0402)\end{array}$ & $\begin{array}{c}0.0644^{* *} \\
(0.0321)\end{array}$ & $\begin{array}{c}0.0788^{* *} \\
(0.0362)\end{array}$ & $\begin{array}{l}0.0582 * \\
(0.0347)\end{array}$ \\
\hline Observations & 824 & 824 & 824 & 824 & 824 \\
\hline R-squared & 0.198 & 0.231 & 0.249 & 0.233 & 0.214 \\
\hline
\end{tabular}

Notes: An observation is a district $(\mathrm{N}=103) \mathrm{x}$ half year. District Karkh is excluded as national CSP programs are confounded with local there. Means are for levels (NT=927) though regressions are estimated in first differences (NT=824). Incidents are measured per 1000 population. Their mean is 0.587 . Troop strength is measured in battalions per district per capita. Regressions are weighted by population and include year effects, and Sunni vote-year interactions. ${ }^{* * *} \mathrm{p}<0.01,{ }^{* *} \mathrm{p}<0.05,{ }^{*} \mathrm{p}<0.1$. Standard errors are clustered at the district level. 